УДК 591.524.12:574.5

В. М. Трохимець, М. В. Сидоренко, А. В. Подобайло

Київський наиіональний університет ім. Тараса Шевченка

\title{
ЛІТОРАЛЬНИЙ ЗООПЛАНКТОН р. УДАЙ У РАЙОНІ НАЦІОНАЛЬНОГО ПРИРОДНОГО ПАРКУ «ПИРЯТИНСЬКИЙ»
}

Уперше проведено еколого-фауністичний аналіз літорального зоопланктону середньої ділянки р. Удай. Дослідження проведені як складова частина обгрунтування створення у цьому регіоні Національного природного парку «Пирятинський». Встановлено видове різноманіття літорального зоопланктону шести дослідних станцій на р. Удай. Виявлено особливості біотопічного розподілу зоопланктону влітку у денні години. Охарактеризовано біотопічний розподіл зоопланктону різних станцій, основні екологічні показники популяцій зоопланктону (щільність і біомасу).

В. Н. Трохимец, М. В. Сидоренко, А. В. Подобайло

Киевский национальный университет им. Тараса Шевченко

\section{ЛИТОРАЛЬНЫЙ ЗООПЛАНКТОН р. УДАЙ В РАЙОНЕ НАЦИОНАЛЬНОГО ПРИРОДНОГО ПАРКА «ПИРЯТИНСКИЙ»}

Впервые проведен эколого-фаунистический анализ литорального зоопланктона среднего участка р. Удай. Исследования проведены как составная часть обоснования создания в этом районе Национального природного парка «Пирятинский». Установлено видовое разнообразие литорального зоопланктона шести исследованных станций на р. Удай. Выявлены особенности биотопического распределения зоопланктона в дневные летние часы. Дана сравнительная характеристика биотопического распределения зоопланктона разных станций. Охарактеризованы основные экологические показатели популяций зоопланктона (плотность и биомасса).

V. N. Trokhymets, M. V. Sydorenko, A. V. Podobaylo

Taras Shevchenko Kyiv National University

\section{THE UDAY RIVER'S LITTORAL ZOOPLANKTON IN THE REGION OF THE NATIONAL NATURE PARK «PYRIATYNSKIY»}

The ecological-faunistic analysis of the littoral zooplankton of the middle part of the Uday River has been performed for the first time. The research was conducted to confirm a reason to create the National Nature Park «Pyriatynskiy» in this region. The species diversity of the littoral zooplankton obtained from six scientific stations on the Uday River was established. The specific features of the zooplankton's distribution in biotopes in summer days were revealed. The comparative description of biotopical distribution of zooplankton of different stations is presented. The basic ecological indices of zooplankton populations (density and biomass) were determined.

\section{Вступ}

Нині все актуальнішим стає питання дослідження малих і середніх річок, які, створюючи розгалужені мережі, забезпечують надходженням водних мас великі водойми (наприклад, великі річки та водосховища). Особливу увагу привертає Пиря- 
тинський район Полтавської області, через територію якого протікає р. Удай, яка вважається однією з найчистіших в Україні [6]. Проте внаслідок активної меліорації відбулось осушення заплав багатьох приток, які живили Удай. Значний вплив на екосистему річки мають інтенсивні викиди органічних забруднень. Останнє спричинило зменшення видового різноманіття, замулення та заростання річки. Вивчення зоопланктону р. Удай ще не проводили, тому всі дослідження цієї групи гідробіонтів $\epsilon$ «піонерними». Крім того, зоопланктон належить до біоіндикаторів, його використовують для оцінки стану водойм у багатьох країнах світу [9-18]. Особливої актуальності дослідження фауни Пирятинського району набули внаслідок створення на його теренах Національного природного парку «Пирятинський» [8]. Мета цієї роботи - оцінити різноманіття та екологічні особливості літорального зоопланктону р. Удай у межах новоствореного Національного природного парку «Пирятинський».

\section{Матеріал і методи досліджень}

Об'єкт досліджень - представники основних груп зоопланктону: коловертки (клас Rotatoria), гіллястовусі ракоподібні (ряд Cladocera) та веслоногі ракоподібні (клас Copepoda). Враховували також черепашкових ракоподібних (клас Ostracoda), ідентифікацію яких проводили до класу. Матеріалом слугував зоопланктон, зібраний у серпні 2010 року в межах 6 дослідних станцій (рис. 1): околиці с. Кроти (N 50²3,412', Е $\left.32^{\circ} 28,358^{\prime}\right)$, с. Леляки (N 50²0,175', Е 32²9,318'), с. Кейбалівка (N 50¹8,387',

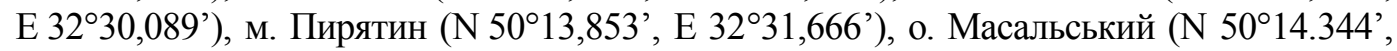
Е $\left.32^{\circ} 28,358^{\prime}\right)$, с. Повстин (N 50¹1.180', Е $\left.32^{\circ} 40.241^{\prime}\right)$.

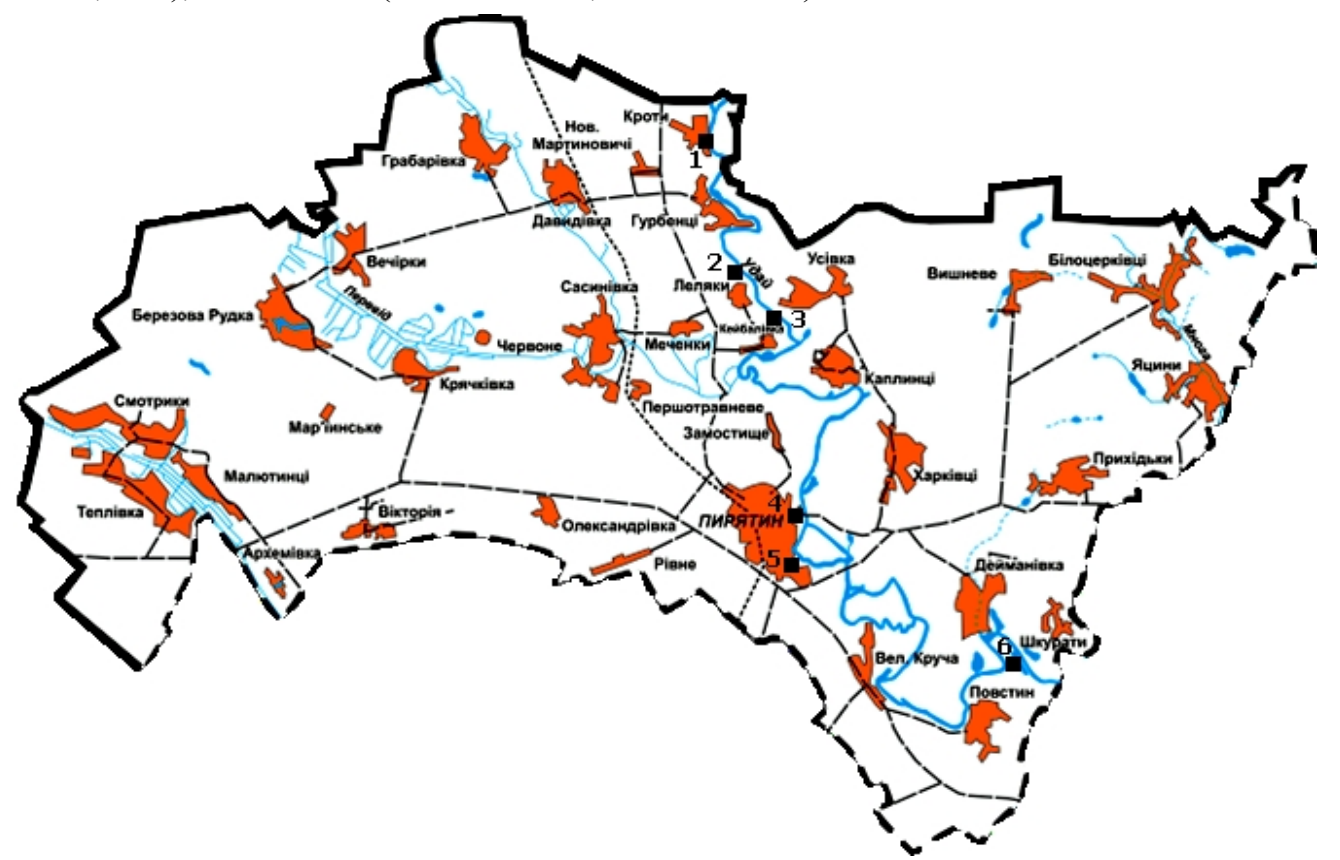

Рис. 1. Карта-схема Пирятинського району зі станціями відбору проб на річці Удай: 1 - околиці с. Кроти, 2 - с. Леляки, 3 - с. Кейбалівка,

4 - м. Пирятин, 5 - о. Масальський, 6 - с. Повстин

Для кожної станції, за можливості, обирали по два біотопи: зарослий - iз вищою водною рослинністю, незарослий - чисті від рослинності ділянки. Збирання матеріалу проводили конічною планктонною сіткою [1], а його аналіз - загальноприйнятими ме- 
тодами [2-5; 7]. Слид відзначити, що показники ступеня розвитку зоопланктону, чистоти води, трофності водойм визначали за допомогою спеціальної таблиці [4] на основі отриманих показників щільності та біомаси. Наприклад, дуже низький ступінь розвитку зоопланктону: щільність - менше 5000 екз. $\mathrm{m}^{3}$, біомаса - менше $0,3 \mathrm{r} / \mathrm{m}^{3}$, стан води відмінний, ступінь чистоти - дуже чиста, трофність водойми - оліготрофна-олігомезотрофна тощо.

\section{Результати та їх обговорення}

Під час літніх досліджень у межах шести дослідних станцій на річці Удай в межах НПП «Пирятинський» у складі зоопланктону виявлено 46 видів тварин. Коловертки представлені 19 видами (41,3 \% загальної кількості видів): Asplanchna priodonta Gosse, 1850, Brachionus amphiceros Ehrenberg, 1838, B. quadridentatus Hermann, 1783 (п'ять підвидів - B. q. brevispinus Ehrenberg, 1832; B. q. quadridentatus Hermann, 1783; B. q. cluniorbicularis Skorikov, 1894; B. q. melheni Barrois and Daday, 1894; B. q. zernovi Voronkov, 1907), Cephalodella gibba (Ehrenberg, 1830), Colurella uncinata (O. F. Müller, 1773), Conochilus unicornis Rousselet, 1892, Euchlanis deflexa (Gosse, 1851), E. dilatata Ehrenberg, 1832, E. incisa Carlin, 1939, Lecane bulla (Gosse, 1851), L. luna (O. F. Müller, 1776), L. quadridentata (Ehrenberg, 1830), L. ungulata (Gosse, 1887), Lepadella patella (O. F. Müller, 1773), Mytilina ventralis (Ehrenberg, 1832), Plationus patulus (O. F. Müller, 1786), Platyias quadricornis (Ehrenberg, 1832), Testudinella patina (Hermann, 1783), Trichocerca rattus (O. F. Müller, 1776).

Гіллястовусі ракоподібні представлені 19 видами (41,3 \%): Acroperus harpae (Baird 1834), Alona rectangula Sars, 1862, Alonella excisa (Fischer, 1854), A. exiqua (Lilljeborg 1853), Biapertura affinis (Leydig, 1860), Bosmina longirostris (O. F. Müller, 1776), Camptocercus rectirostris Schoedler, 1862, Ceriodaphnia affinis Lilljeborg, 1900, Chydorus latus Sars, 1862, Ch. sphaericus (O. F. Müller, 1785), Daphnia cucullata Sars, 1862, Diaphanosoma brachyurum (Liévin, 1848), Graptoleberis testudinaria (Fischer, 1848), Ilyocryptus acutifrons Sars, 1862, Oxyurella tenuicaudis (Sars, 1862), Pleuroxus laevis Sars, 1862, Rhynchotalona rostrata (Koch, 1841), Sida crystallina (O. F. Müller, 1776), Simocephalus vetulus (O. F. Müller, 1776).

Веслоногі ракоподібні були найменш різноманітні - 8 видів (17,4 \%): Acanthocyclops americanus (Marsh, 1893), A. viridis (Jurine, 1820), Cryptocyclops bicolor (Sars, 1863), Eucyclops serrulatus (Fischer, 1851), Macrocyclops albidus (Jurine, 1820), Mesocyclops leuckarti (Claus, 1857), Paracyclops fimbriatus (Fischer, 1853), Thermocyclops crassus (Fischer, 1853). За фауністичним спектром угрупування переважали представники ротаторно-кладоцерного комплексу. Враховували також молодих особин гіллястовусих ракоподібних, наупліальні та копеподитні личинкові стадії розвитку веслоногих ракоподібних, а також черепашкових ракоподібних. Проте визначення цих груп зоопланктону проводили до надвидових таксонів, а дані враховували під час аналізу показників щільності та біомаси.

Станиія № 1 поблизу с. Кроти. У фауністичному спектрі угрупування літорального зоопланктону зарослого біотопу коловертки склали 43 \% (9 видів) загальної кількості видів зоопланктону (21 вид), гіллястовусі ракоподібні - $24 \%$ (5 видів), веслоногі ракоподібні - 33 \% (7 видів). У незарослому біотопі (21 вид) відповідно 38 \% (8 видів), 48 \% (8 видів) і 24 \% (5 видів). Індекси підтвердили високий ступінь подібності видового складу різних біотопів: $J$ (індекс Жаккара) -69 ; $\mathrm{J}_{\text {дом. }}$ (індекс Жаккара домінантний) - 100. Щільність літорального зоопланктону цієї станції склала (рис. 2) у зарослому біотопі 10620 екз./ м $^{3}$, у незарослому - 3060 екз./ м $^{3}$. Із груп 
зоопланктону в межах зарослого біотопу домінували веслоногі ракоподібні - $46 \%$ $\left(4860\right.$ екз./ м $^{3}$. У незарослому біотопі переважали коловертки - 37,3 \% (1 140 екз./ $\left.\mathrm{m}^{3}\right)$, незначно їм поступалися веслоногі ракоподібні - 29,4 \% (900 екз./ $\left.{ }^{3}\right)$. Чітко вираженого домінанта не було, проте в межах зарослого та незарослого біотопів за щільністю

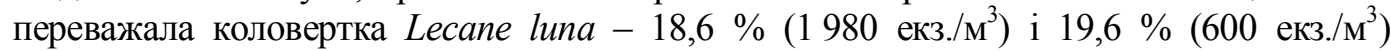
відповідно. Біомаса літорального зоопланктону цієї станції склала (рис. 3): зарослий біотоп $-0,27 \Gamma / \mathrm{M}^{3}$, незарослий $-0,14 \Gamma / \mathrm{M}^{3}$. За біомасою в зарослому біотопі переважали веслоногі ракоподібні - 44,6 \% $\left(0,12 \Gamma^{3} \mathrm{M}^{3}\right)$, у незарослому - черепашкові - 49,5\% $\left(0,068 \Gamma / \mathrm{M}^{3}\right)$ та веслоногі ракоподібні - 39,2\% $\left(0,054 \mathrm{r} / \mathrm{m}^{3}\right)$. Домінантом у межах зарослого біотопу був Macrocyclops albidus $\left(17,7 \%, 0,048 \mathrm{r} / \mathrm{m}^{3}\right)$. У незарослому біотопі домінанта важко визначити, оскільки переважали черепашкові ракоподібні та личинкові стадії веслоногих ракоподібних. Таким чином, ступінь розвитку зоопланктону за щільністю в межах зарослого біотопу низький, а незарослого - дуже низький. Ступінь розвитку зоопланктону за біомасою в межах обох біотопів характеризувався дуже низькими показниками. Подібні показники відповідають відмінному стану дуже чистих оліготрофних-олігомезотрофних вод.

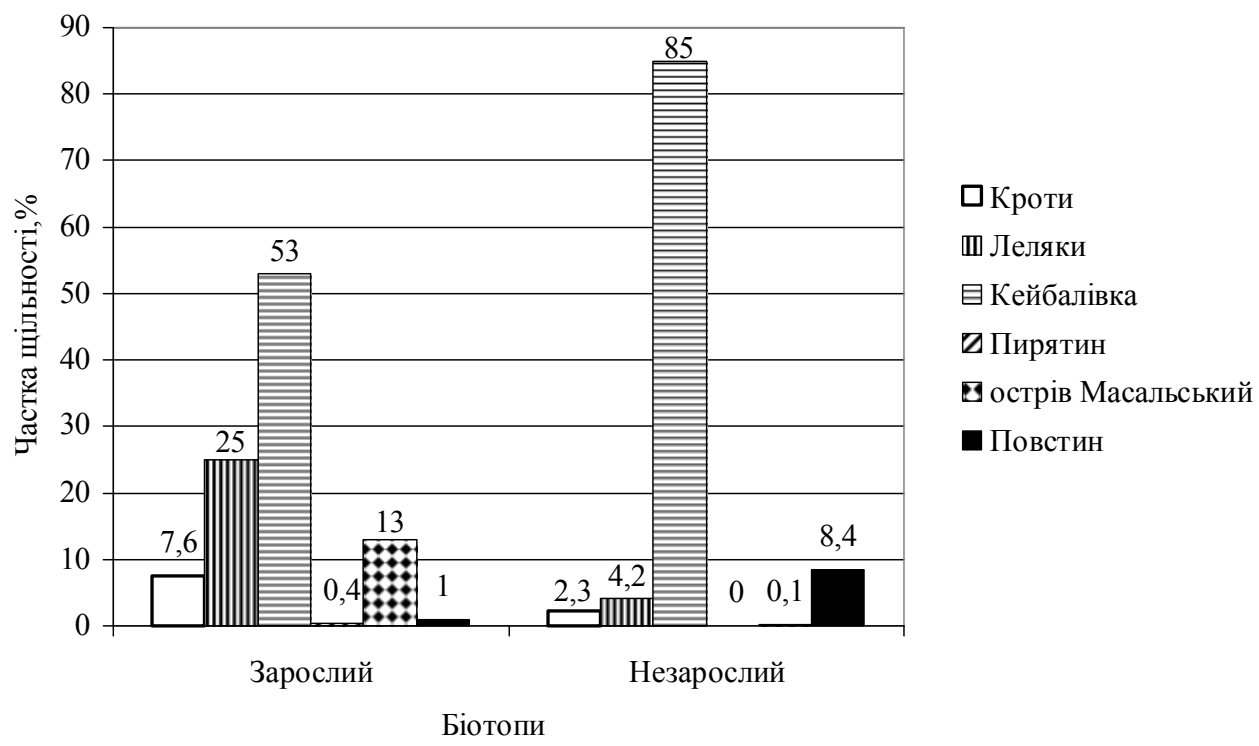

Рис. 2. Щільність зоопланктону зарослого та незарослого біотопів у межах шести базових станцій НПП «Пирятинський»

Станція № 2 поблизу с. Леляки. У фауністичному спектрі угрупування зарослого біотопу коловертки склали $28 \%$ (5 видів) кількості видів зоопланктону (18 видів), гіллястовусі ракоподібні - $44 \%$ (8), веслоногі ракоподібні - 28 \% (5). У незарослому біотопі (9 видів) - відповідно 11 \% (1 вид), 56 \% (5) і 33 \% (3). Індекси підтвердили низький рівень подібності видового складу різних біотопів: $J=16, J_{\text {до. }}=0$. Щільність літорального зоопланктону цієї станції склала (див. рис. 2): зарослий біотоп - 34840 , незарослий - 540 екз./ $\mathrm{m}^{3}$. У межах зарослого біотопу переважали веслоногі ракоподібні - 46,4 \% (16 160 екз./ $\left.\mathrm{m}^{3}\right)$. У незарослому біотопі, зоопланктон якого характеризувався дуже низькими кількісними показниками, переважали гіллястовусі ракоподібні $66,7 \%$ (360 екз. $\left./ \mathrm{m}^{3}\right)$. Домінантом у межах зарослого біотопу був Acroperus harpae - 
$19,5 \%$ щільності зоопланктону (6 800 екз./ $\left.\mathrm{M}^{3}\right)$. У межах незарослого біотопу домінував за щільністю Alona rectangula - 33,3 \% $\left(180\right.$ екз./ $\left.\mathrm{m}^{3}\right)$. Біомаса літорального зоопланктону цієї станції склала (див. рис. 3): зарослий біотоп - 1,360, незарослий $-0,013 \mathrm{r} / \mathrm{m}^{3}$. За біомасою у зарослому біотопі переважали черепашкові ракоподібні - 43,2 \%

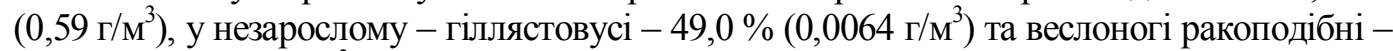
$44,5 \%\left(0,0058 \Gamma / \mathrm{m}^{3}\right)$. Для зарослого біотопу характерна мезодомінантність, коли декілька видів веслоногих ракоподібних малють приблизно однакову біомасу: Macrocyclops albidus - $10 \%\left(0,130 \Gamma / \mathrm{M}^{3}\right)$, Acanthocyclops viridis $-8 \%\left(0,108 \Gamma / \mathrm{m}^{3}\right) \mathrm{i}$ Eucyclops serrulatus - $7 \%\left(0,101 \Gamma^{3} \mathrm{~m}^{3}\right)$. У незарослому біотопі вираженого домінанта не було. Ступінь розвитку зоопланктону за щільністю в межах зарослого біотопу був низький, незарослого - дуже низький. Ступінь розвитку зоопланктону за біомасою: зарослий - нижче середнього, незарослий - дуже низький. Подібні показники відповідають дуже доброму стану чистих мезотрофних вод.

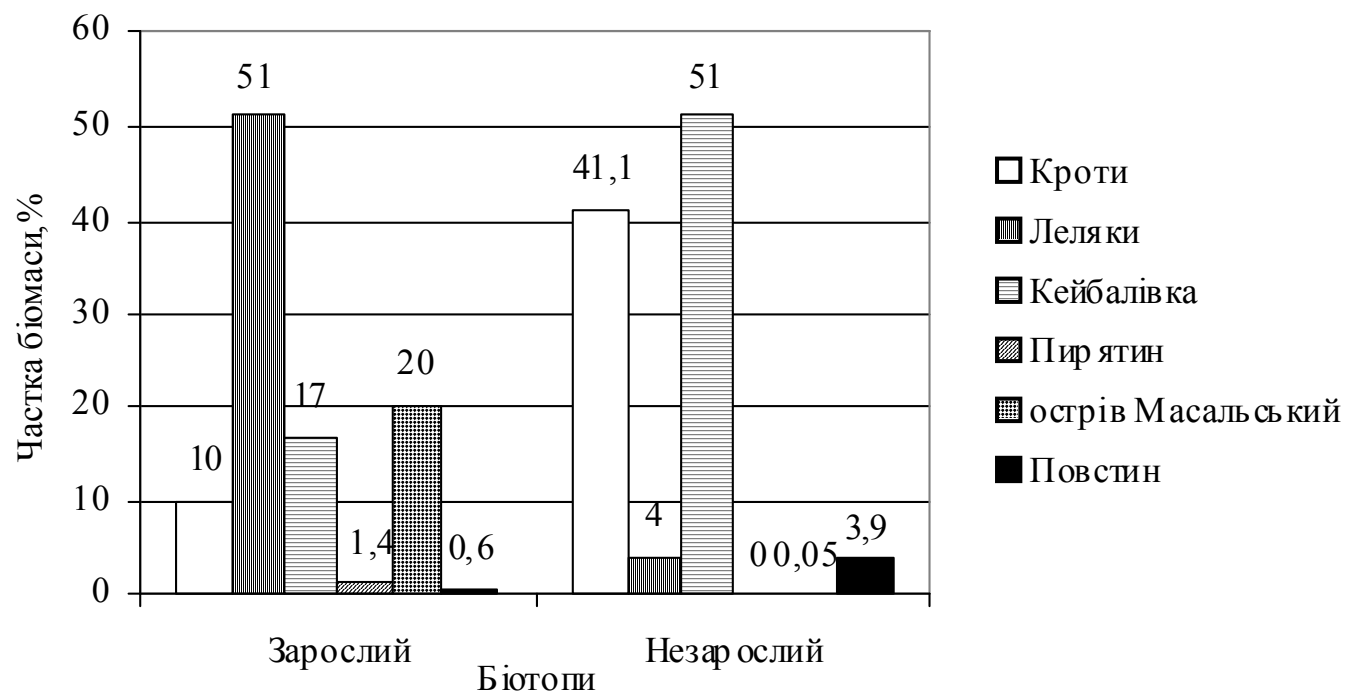

Рис. 3. Біомаса зоопланктону зарослого та незарослого біотопів у межах шести базових станцій НПП «Пирятинський»

Станиія № 3 поблизу с. Кейбалівка. У фауністичному спектрі угрупування зарослого біотопу коловертки склали 29 \% (5 видів) кількості видів зоопланктону (17 видів), гіллястовусі ракоподібні - 47 \% (8), веслоногі ракоподібні - $24 \%$ (4). У незарослому біотопі (8 видів) - відповідно 25 \% (2 види), 38 \% (3) і 38 \% (3). Індекси підтвердили невисокий ступінь подібності видового складу різних біотопів: $J=41$ і $J_{\text {дом. }}=50$. Щільність літорального зоопланктону склала (див. рис. 2): зарослий біотоп - 74 080, незарослий 10880 екз./ ${ }^{3}$. За щільністю в межах зарослого біотопу переважали коловертки $-61,9 \%$ $\left(45840\right.$ екз. $\left./ \mathrm{M}^{3}\right)$. У незарослому біотопі, зоопланктон якого характеризувався значно нижчими показниками, переважали веслоногі ракоподібні - 37,7 \% (4 100 екз./ м $\left.^{3}\right)$. Домінантом у межах зарослого біотопу була коловертка Testudinella patina - $60 \%$ (44 520 екз./ $\left.\mathrm{M}^{3}\right)$. У незарослому біотопі домінували коловертка T. patina - 27,5\% (3 000 екз./ $\left.\mathrm{M}^{3}\right)$ і гіллястовусий рачок Pleuroxus laevis - 18,8 \% (2 040 екз./м $\left.{ }^{3}\right)$. Для зарослого біотопу характерна олігодомінантність, для незарослого - мезодомінантність. Біомаса літорального зоопланктону цієї станції склала (див. рис. 3): зарослий біотоп $-0,465$ г/м ${ }^{3}$, незарослий $-0,180 \mathrm{r} / \mathrm{m}^{3}$. За біомасою у зарослому біотопі переважали веслоногі 
ракоподібні - 50,3 \% $\left(0,23 \mathrm{r}_{\mathrm{M}}^{3}\right)$, у незарослому - гіллястовусі ракоподібні - 49,3\% $\left(0,089 \Gamma / \mathrm{M}^{3}\right)$. У межах обох біотопів за біомасою домінував P. laevis: зарослий $-27,1 \%$ $\left(0,13 \Gamma / \mathrm{M}^{3}\right)$, незарослий $-33,8 \%\left(0,061 \Gamma / \mathrm{M}^{3}\right)$. Ступінь розвитку зоопланктону за щільністю в межах зарослого біотопу був нижчий середнього, незарослого - низький. Ступінь розвитку зоопланктону за біомасою: зарослий - низький, незарослий - дуже низький. Подібні показники відповідають дуже доброму стану чистих мезотрофних вод.

Станиія № 4 поблизу м. Пирятин. Необхідно відзначити, що це єдина станція, де вдалось виділити тільки зарослий біотоп. У фауністичному спектрі угрупування коловертки склали 50 \% (1 вид) кількості видів (2 види), гіллястовусі ракоподібні - 50 \% (1 вид), серед веслоногих ракоподібних наявні лише копеподитні личинкові стадії. Кількісні показники характеризувалися як дуже низькі [5]: щільність - 500 екз./ $\mathrm{m}^{3}$, біомаса - 0,037 $\mathrm{\Gamma} / \mathrm{m}^{3}$. Переважали черепашкові ракоподібні $-72,0 \%\left(360\right.$ екз. $\left./ \mathrm{M}^{3}\right) \mathrm{i}$ $96,4 \%\left(0,036 r / \mathrm{M}^{3}\right)$. Домінантів важко виділити, оскільки зоопланктон представлений лише двома видами. Ступінь розвитку зоопланктону за щільністю та біомасою дуже низький. Подібні показники відповідають відмінному стану дуже чистих оліготрофних-олігомезотрофних вод.

Станція № 5 поблизу о. Масальський. У фауністичному спектрі угрупування зарослого біотопу коловертки склали $40 \%$ (6 видів) кількості видів зоопланктону (15 видів), гіллястовусі ракоподібні - $40 \%$ (6 видів), веслоногі ракоподібні - $20 \%$ (3 види). У незарослому біотопі відсутні статевозрілі представники всіх трьох груп зоопланктону, спостерігалися лише личинкові стадії Cyclopoida juv. Індекси підтвердили повну відсутність подібності: $J=0$ i $J_{\text {дом. }}=0$. Щільність літорального зоопланктону цієї станції склала (див. рис. 2): зарослий біотоп - 19000 екз./ $\mathrm{M}^{3}$, незарослий - 20 екз./ $\mathrm{M}^{3}$. За щільністю в межах зарослого біотопу переважали веслоногі ракоподібні - 63,2 \% $\left(12000\right.$ екз./ $\left.\mathrm{m}^{3}\right)$. Домінант не виражений. Біомаса літорального зоопланктону цієї

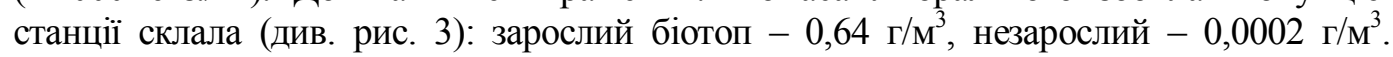
За біомасою в межах зарослого біотопу переважали гіллястовусі ракоподібні (рис. 3 ) $49 \%\left(0,31 \Gamma \mathrm{m}^{3}\right)$. Чітко вираженим домінантом був Sida crystallina $-47 \%\left(0,3 \mathrm{r} / \mathrm{m}^{3}\right)$ сумарної біомаси зоопланктону. Ступінь розвитку зоопланктону за щільністю в межах зарослого біотопу низький, незарослого - дуже низький. Ступінь розвитку зоопланктону за біомасою: зарослий - низький, незарослий - дуже низький. Подібні показники відповідають відмінному стану дуже чистих оліготрофних-олігомезотрофних вод.

Станиія № 6 поблизу с. Повстин. У фауністичному спектрі угруповання зарослого біотопу коловертки склали 50 \% (4 види) кількості видів зоопланктону (8 видів), гіллястовусі ракоподібні - 38 \% (3 види), веслоногі ракоподібні $12 \%$ (1 вид). У незарослому біотопі коловертки склали 50 \% (3 видів) кількості зоопланктону (6 видів), гіллястовусі ракоподібні - 50 \% (3 види), серед веслоногих ракоподібних наявні лише личинкові стадії. Індекси підтвердили невисоку подібність видового складу різних біотопів: $J=31$ і $J_{\text {дом. }}=100$. Щільність літорального зоопланктону цієї станції склала (див. рис. 2): зарослий біотоп - 1340 , незарослий - 1200 екз./м³. За щільністю в межах зарослого біотопу незначно переважали коловертки - 34,3\% (460 екз./ $\left.\mathrm{m}^{3}\right)$. У незарослому біотопі переважали веслоногі ракоподібні - 43,3 \% (520 екз./ $\left.{ }^{3}\right)$. Домінантом у межах зарослого та незарослого біотопів - Bosmina longirostris - $22 \%\left(300\right.$ екз./ $\left.\mathrm{M}^{3}\right)$ i $28 \%\left(300\right.$ екз. $\left./ \mathrm{m}^{3}\right)$. Біомаса літорального зоопланктону склала (див. рис. 3): зарослий біотоп $-0,021$, незарослий $-0,013 \Gamma / \mathrm{m}^{3}$. За біомасою у зарослому біотопі переважали черепашкові ракоподібні - 47,5 \% $\left(0,010 \quad \Gamma / \mathrm{M}^{3}\right)$, у незарослому - гіллястовусі ракоподібні - 44,4 \% $\left(0,006\right.$ г/ $\left.\mathrm{m}^{3}\right)$. Виражених домінантів за біомасою не виділили, оскільки показники ії в окремих видів дуже низькі. Ступінь розвитку зоопланктону за 136 
щільністю та біомасою дуже низький у межах обох біотопів. Подібні показники відповідають відмінному стану дуже чистих оліготрофних-олігомезотрофних вод.

\section{Висновки}

За фауністичним спектром угрупування (46 видів) переважали представники ротаторно-кладоцерного комплексу (коловертки - 19 видів, гіллястовусі - 19 і веслоногі ракоподібні - 8 видів).

Порівняльний аналіз видового складу зоопланктону різних біотопів підтвердив для майже всіх станцій низький рівень подібності між зарослим і незарослим біотопами $-J=0-41$. Виняток становила тільки станція в околицях с. Кроти $(J=69)$, що можна пояснити розміщенням біотопів на близькій відстані один від одного.

Щільність і біомаса дуже низькі (менше 5000 екз./ $/ \mathrm{m}^{3}$ і менше $0,3 \mathrm{r} / \mathrm{m}^{3}$ ) чи низькі

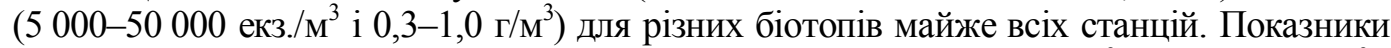
розвитку зоопланктону, нижчі за середні (51 000-250000 екз./ $\left.\mathrm{m}^{3} \mathrm{i} 1,1-5,0 \mathrm{r} / \mathrm{m}^{3}\right)$, характерні для зарослих біотопів станції в околицях с. Кейбалівка $\left(74080\right.$ екз./ $\left.\mathrm{m}^{3}\right)$, біомаси в межах зарослого біотопу с. Леляки $\left(1,36 \mathrm{r} / \mathrm{M}^{3}\right)$.

Аналіз літорального зоопланктону дає підстави стверджувати, що вода в межах різних біотопів більшості досліджених станцій характеризується відмінним або добрим станом, за ступенем чистоти - дуже чиста або чиста, за трофністю належить до оліготрофних, олігомезотрофних або мезотрофних водойм.

\section{Бібліографічні посилання}

1. Жадин В. Н. Методы гидробиологического исследования. - М. : Высшая школа, 1960. $192 \mathrm{c}$.

2. Кутикова Л. А. Коловратки фауны СССР. - Л. : Наука, 1970. - 744 с.

3. Мануйлова Е. Ф. Ветвистоусые рачки (Cladocera) фауны CССР. - М.-Л. : Наука, 1964. $327 \mathrm{c}$.

4. Методи гідроекологічних досліджень поверхневих вод / О. М. Арсан, О. А. Давидов, Т. М. Дьяченко та ін. - К. : ЛОГОС, 2006. -408 с.

5. Монченко В. І. Щелепнороті циклоподібні, циклопи / Фауна України. - Т. 27, вип. 3. - К. : Наукова думка, 1974. - 450 с.

6. Оцінка якості води річки Удай у межах національного природного парку «Пирятинський»/ М. В. Сидоренко, Р. С. Світін, В. Б. Катрій, А. В. Подобайло // Роль національного природного парку «Пирятинський» в природно-заповідній та екологічній мережах Полтавщини: Матер. Веукр. екол. наук.-практ. конф. - К. : Просвіта, 2011. - С. 57-62.

7. Песенко Ю. А. Принципы и методы количественного анализа в фаунистических исследованиях. - М. : Наука, 1982. - 287 с.

8. Шевчик В. Л. Наукове обгрунтування створення Національного природного парку «Пирятинський» / В. Л. Шевчик, А. В. Подобайло, О. О. Сенчило. - К., 2009. - 23 с.

9. Bio-survey of Plankton as indicators of water quality for recreational activities in Calabar River, Nigeria / E. C. Uttah, C. Uttah, P. A. Akpan et al. // J. Appl. Sci. Environ. Manage. - 2008. - Vol. 12, N 2. - P. 35-42.

10. Ceirans A. Zooplankton indicators of trophy in Latvian lakes // Acta Universitatis Latviensis. 2007. - Vol. 723. - P. 61-69.

11. Lake ecosystems health assessment: Indicators and methods / Xu Fu-Liu, Tao Shu, R. W. Dawson et al. // Wat. Res. - 2001. - Vol. 35, N 13. - P. 3157-3167.

12. Lougheed V. L. Development and use of a zooplankton index of wetland quality in the Laurentian Great Lakes basin / V. L. Lougheed, Chow-Fraser // Ecological Applications. - 2002. - Vol. 12, N 2. - P. 474-486. 
13. Monitoring water quality using zooplankton organisms as bioindicators at the Dubica fish farm, Serbia / Z. Dulic, V. Mitrovic-Tutundzic, Z. Marcovic, I. Zivic // Arch. Biol. Sci. - 2006. Vol. 58 (4). - P. 245-248.

14. Nikleka E. Zooplankton species as biological indicators of the water of Bovilla reservoir / E. Nikleka, S. Shumka, S. Mali // Natura Montenegrina, Podgorica. - 2006. - Vol. 7, N 2. - P. 253-259.

15. Nogueira M. G. Zooplankton assemblages (Copepoda and Cladocera) in a cascade of reservoirs of a large tropical river (SE Brazil) / M. G. Nogueira, P. C. R. Oliveira, Y. Tenorio de Britto // Limnetica. - 2008. - Vol. 27, N 1. - P. 151-170.

16. Paturej E. A zooplankton-based study of coastal lakes // Baltic Coastal Zone. - 2009. - N 13. P. 25-32.

17. Shayestehfar A. Environmental factor effects on the seasonally changes of zooplankton density in Parishan Lake (Khajoo Spring site), Iran / A. Shayestehfar, M. Noori, F. Shirazi // Asian J. Exp. Biol. Sci. - 2010. - Vol. 1, N 4. - P. 840-844.

18. Study of Zooplankton Diversity of Nira Left Bank Canal Schardanagar Tal Baramati dist Pune with Reference to Physico Chemical Parameters / U. S. Ghantaloo, J. P. Sarwade, A. F. Gaikwad, S. M. Kamble // Recent Researchin Science and Technology. - 2011. - Vol. 3, N 3. - P. 125-128.

Надійшла до редколегї 23.12.2011 